\title{
The 'Online High Street' or the High Street Online? The Implications for the Urban Retail Hierarchy
}

\begin{abstract}
The UK has the greatest proportion of online sales in Europe. This study seeks to explore the differential effects of online retailing on the (evolving) hierarchy of shopping centres by examining current trends and underlying forces. The overall objectives of the paper are to qualify and explore the influence of online retailing in the decision making processes of leading retailers today; and to assess how virtual influences become manifest in the tangible built environment and have impacted the retail hierarchy? It differentiates online retail trends by sector and retailer size, and examines the consequences for different types of shopping centres. The empirical research is based on the changing location of stores of a major fashion retailer and interviews with three of Britain's leading retailers that have seen the more substantial increase in online turnover in recent years. Major retailers are found to have integrated online offerings, such as click and collect, into a 'multi-channel' retailing approach. Online retailing has therefore become an inherent and central element within large retailers' business and therefore real estate strategies, with considerations such as online marketplace penetration and possible 'cannibalisation' coming to the fore in decision making about store location. Online retail sales are, to a degree, drawing sales away from shopping centres but its impact on the existing shopping hierarchy is largely to reinforce established long term trends driven by the motor age and the shift to out of town retailing. This is symbolised by the largest 'high street' fashion retailer now having more branches in retail parks than town centres. Out of town shopping centres for example are benefitting because of the ease of goods collection offered by these locations.
\end{abstract}

Keywords: Online retailing, shopping centres, high street, out of town, retail hierarchy 


\section{Introduction}

The impact of online shopping on the retail hierarchy is the subject of continuing dispute. There is little doubt that online consumption has transformed retailing. The English language has embraced new phrases - 'click and collect', 'one-click purchasing', 'and freshly clicked', as online retailing has developed. These have grown in common parlance as internet sales expanded in the UK: it is the most developed online market in the world (Cushman and Wakefield, 2013). Recent figures indicate that online retailing in the UK accounted for $15.8 \%$ of all retailing in late 2016 (ONS, 2016a). At the centre of the debate around the impact of online retailing in the UK are questions surrounding the role and resilience of the traditional shop and town centres (Wrigley and Lambrini, 2014). The last decade or so has seen a continuing barrage of usually negative predictions about high street sales moving online and consequently, the decline of independent local retailers. This literature does not systematically differentiate on the role/type of shopping centre (Digital High Street Advisory Board, 2015). This paper offers an investigation into the influence of the growth in online consumption on the retail hierarchy, assessing nuances in retailer behaviour and locational trends. Is online retail the major driver for change; how influential is its emergence for retailers?

From January 2007 internet sales as a proportion of total retail sales in the UK grew from $2.7 \%$ to $11.5 \%$ in November 2014 , amounting to an average weekly spend of $f 753.4 \mathrm{~m}$. How the continuing growth in internet sales manifests itself has wide ranging implications not just for retailers but also for consumers, investors and the economy. The retail market employs approximately 3 million people, and accounts for more than $10 \%$ of total UK employment (BRC, 2012). There are currently almost half a million shops operating in the UK and the value of commercial retail property is $f 293 \mathrm{bn}$, representing $45 \%$ of the commercial property stock in 2013 (Mitchell, 2014).

Internet retailing has been examined from various perspectives in literature, with its evolution considered in numerous books (Laudon and Traver, 2012; Chaffey et al, 2009; Charlesworth, 2009); and journal articles relating to marketing (eg Barlow et al, 2004), consumers (eg Rohm and Swaminathan), management and business strategy (eg Rowley, 2009). Recent reviews of the emergence of the internet on UK retailing include Jones and Livingstone (2015a), Doherty and Ellis-Chadwick (2010) and Hammerson (2014). This research has examined online retailing from the retailers' or consumers' point of view but lacks any detailed 
appraisal of the impact on shopping centres. The significant contribution of this paper is that it distinguishes the differential impacts on real estate and types of shopping centres. The research determines 'shopping centres' as anywhere there is a concentration of retail units, irrespective of location, e.g. local high streets, retail parks (collections of big box units with car parking) in decentralised locations, out of town shopping malls and city centres.

There is no doubt that some UK retailers have responded to the internet by offering 'multi-channel' (or 'omni-channel') retailing, providing consumers with various media through which to browse and purchase in addition to in-store shopping; including online stores, mobile applications (via phones, tablets and laptops) and social media. What is less clear is what this has meant for real estate requirements and shopping centres. This paper specifically assesses the influence of this shift towards the virtual so far, considering its effect on the evolving functional role of physical retail space and on its locations. It addresses the interconnected relationship between virtual and physical retailing and the consequences for shopping centres and the retail hierarchy. The overall objectives of the paper are to qualify and explore the influence of online retailing in the decision making processes of leading retailers today; and to assess how virtual influences become manifest in the tangible built environment and have impacted the retail hierarchy?

The paper is based on both primary and secondary sources. Insight into historic trends is offered through an analysis of the types of shopping centre locations of the portfolio of Next stores across the UK. Finally, the paper reports on semi-structured interviews with property directors and acquisition managers of three leading UK 'high street' retailers to assess the interaction between their real estate and on-line retailing strategies.

This paper begins by analysing the changing UK retail context and the long term forces that have shaped shopping centres, such as the car, and the recent recession. Historic perspective on online and multi-channel sales is then considered, summarising recent trends in online retail sales with a key message of the pace of change. The differential physical real estate response to online sales is then reviewed distinguishing the strategies of retail sectors and types of retailers. The next section focuses on the strategies of fashion and department store chains. It begins with a case study of the (changing) store network of Next, the largest fashion retailer in the UK. The latter part examines the real estate strategies of three large multiple retailers based on semi-structured interviews. Finally the paper summarises the arguments and draws together 
our findings, including the ramifications for the high street, types of shopping centres and the retail hierarchy.

\section{The changing retail hierarchy}

Prior to reviewing the influence of the internet on stores and shopping centres since the turn of the millennium it is important to consider the wider historical retail context. Beginning in the 1970s the car began to transform shopping patterns and retail development. It resulted in a grocery-led flight from town centres followed by new out of town retail forms, first retail warehouses, then retail parks and then regional centres (Schiller, 1986). Retail warehouses began to be built in the early 1980s and were eventually grouped within retail parks. Retail warehouse development expanded at pace, amounting to over $4 \mathrm{~m}$ square feet per annum on average in the thirteen years up to 2006 before the property market downturn brought a rapid contraction: in 2014 (CBRE, 2014a). In addition there has been a substantial expansion of out of town shopping centres, as shown in Figure 1, at an historically high level over recent decades despite greater planning constraints on out of town development since 1994 (Jones, 2014).

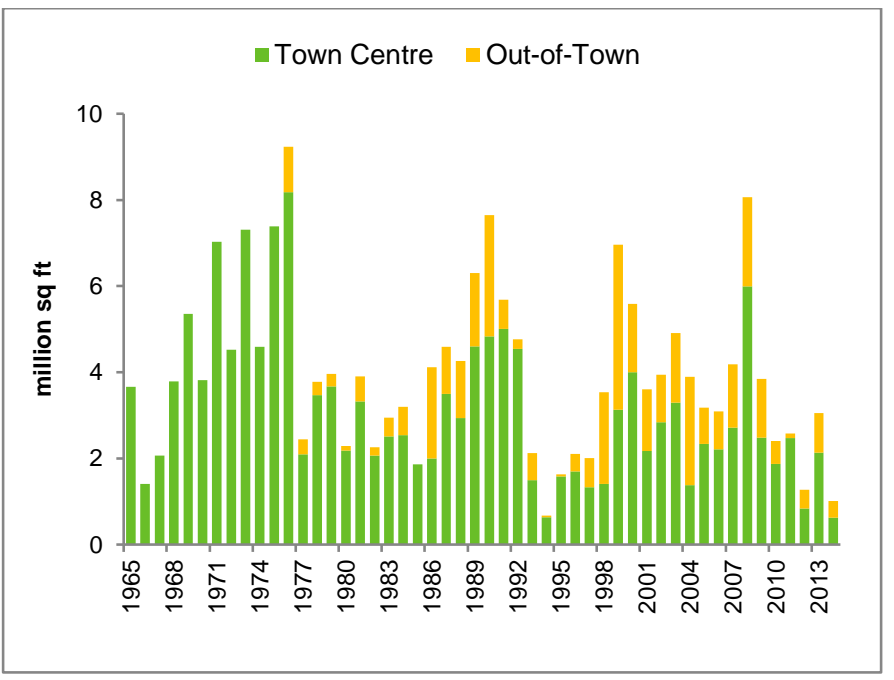

Figure 1 Annual completions of town centre and out-of-town shopping centres

Source: CBRE (2014b)

Both retail parks and out of town shopping centres have come to represent seriously damaging threats to town centres (Guy, 2000; Thomas et al, 2006). This has arisen because retail parks attracted national retailers from the traditional high street and there is increasing overlap in the goods available for sale. In fact the nature of retail parks is evolving away from their initial focus 
on bulky goods, with 'fashion parks' a new phenomenon. As of December 2014 there were 21 fashion parks in the development pipeline, amounting to $2.7 \mathrm{~m} \mathrm{sq} \mathrm{ft}$., with more than half of this space $(1.6 \mathrm{~m}$ sq ft.) under construction. This exceeds the total for bulky goods parks (CBRE, 2014a).

Over decades town centres have also evolved with new shopping malls built and the greater flexibility to consumers offered by this format led to the decline of department stores, the traditional anchors of these high street locations (Jones and Orr, 1999). Figure 1 demonstrates that 'in town' centre development began in earnest at the end of the 1980s but especially took hold from the mid1990s. In parallel there has been a long term expansion of multiple retailers, many of whom are now trans-national companies (Durand and Wrigley, 2009). As a consequence, the rise and influence of 'brand power' has proven magnetic to shoppers. New shopping malls have also been driven by these brands requiring larger shops with many small shops at the periphery of major shopping centres now obsolete, and converted to alternative uses (Crosby et al, 2005).

At the end of the 1980s a retail hierarchy could be framed almost entirely in terms of town centres. Reynolds and Schiller (1992) discerned a five tier retail hierarchy for the UK from 370 minor district centres through to 6 provincial cities based on the number of multiple retailers in each locality. Almost a quarter of a century later Dolega et al (2016) derive a similar retail hierarchy using a more complex additive composite index based on centre size, a diversity index, proportions of leisure units and anchor stores, together with vacancy rates.. Their approach produces an equivalent set of tiers but it ignores fundamental long term changes to the roles and the range of shopping centres. The study is still based on town centres, but by including only 25 standalone out of town centres (out of 1312 centres) it is now only a partial picture.

The growth of out of town regional centres and in town shopping malls in cities, combined with improved inter-urban motorways has contributed to a recent 'rationalisation' of the shopping centre landscape. It has brought greater concentration of sales in regional centres. Genecon (2011) links a large increase in clothing and footwear stores in regional centres with a parallel decline in sub-regional and town centres over the period 1998-2010. A parallel story is told by Jones and Livingstone (2015b) who demonstrate that the relative rental spectrum between centres widened between high order and low order retail centres from the mid-1980s to 2015. This trend is shown to have accelerated in the first half of the last decade (prior to the emergence of online). 
Traditional small town and local suburban shopping centres have also suffered from the long term rise of the supermarket. Supermarkets now account for $97 \%$ of grocery sales and over the last fifty years or so there has been a dramatic decline in high street specialist grocery shops, with the number of greengrocers and butchers for example falling by the order of three quarters (Competition Commission, 2008).

The recession and falling real incomes from the end of the last decade led to a shake out of retailers and visibly confirmed the structural changes to shopping centres discussed above (Wrigley and Dolega, 2011). Vacancy rates in shopping centres rose to unprecedented levels. The Local Data Company (2011) commented that vacancies were not spread evenly across types of shopping centres, and that taken together with other market indicators the evidence demonstrated that prime sites are taking market share away from other locations. That is not to say that retail parks and out of town shopping centres were unaffected. The failings of traditional shopping centres, and some retailers on retail parks to a degree, can also be attributed to the rise of online shopping in the latter part of the noughties, especially impacting certain sectors such as bulky goods and standardised products (Weltevreden, 2007; Wrigley and Lambiri, 2014).

The long term consequences of these trends are that traditional small town shopping centres still exist but their fashion and food retailing roles have been significantly diminished. In the UK the problems have been stressed in a series of well publicised reports, notably Portas (2012), that emphasise the relative disadvantages of high streets compared with out of town shopping, especially the availability and cost of car parking. The problem of these reports is that they have been framed narrowly in terms of the high streets of (small) town centres, but structural change has been more all-embracing, with impacts on neighbourhood shopping parades through to suburban high streets to district, town and city centre levels.

- The culmination of this structural change driven in the main by a motor age is that there has been an upheaval in the longstanding retail hierarchy. This is part of a much wider restructuring of the spatial economy over the last forty years (Jones, 2016). It may be argued that any retail hierarchy is now at best blurred. Nevertheless the implications of change for retailing have been two fold. First, regional shopping centres have benefitted, whether in town or out of town. Second, traditional local shopping centres are being displaced by retail parks and superstores in decentralised locations with easy car access. 


\section{Historic perspectives on internet retailing}

The adoption of the internet as a retail tool began in the late 1990s initially via pure play (internet only) retailers, with Amazon and EBay both established in 1995. A major expansion in online retailing has occurred over the last decade, as social media and multi-channel interfaces became increasingly commonplace. In 2001 there were four channels through which purchases could be made (physical stores / catalogues / telephone ordering / online via desktop/laptop), but the vast majority of consumers, 66.2\% (Hammerson, 2013), still shopped primarily through physical stores and catalogues. When discussing the view from 2013, Hammerson recognises three additional channels through which consumers can shop (online via mobile/tablet, social media, and interactive TV). From the seven channels through which customers can purchase today, four are entirely online based formats.

The speed of online retail's evolution has spawned a continuing stream of crystal ball gazing about its development. Anticipating the impact of the internet on retailing has stimulated a range of future visions. As early as 1967 Doddy and Davidson (1967) predicted a revolution in how we shop, in line with the substantial technological innovation that was ongoing at the time. In 1996 it was argued that within 40 years, there would be no need for physical stores due to the influence of electronic retailing (Cope, 1996). Certainly, the online retail world has developed at speed, concomitant to technological advances (Digital High Street Advisory Board, 2015). Since the turn of the century and the accelerated emergence of additional sales channels, retailers have had to effectively respond to changes in how people shop; they have had to provide flexibility, rapidly adjusting their sales methods and physical stores in order to remain relevant and competitive in the marketplace.

Access to the internet accelerated globally from the late 1990s and as web connection technology improved and faster browsing opportunities evolved, consumers had increased capacity to engage with online retailing if they so desired. The largest annual percentage increase in internet accessibility in Britain occurred during 2008-09, with an 11\% growth in household connectivity (ONS, 2010). As of 2016, 23.7 million people (89\%) of British households had internet access and $82 \%$ of adults used the internet on a daily basis, with $77 \%$ of adults having bought goods or services online (ONS, 2016b). Over the period 2009-2014 the rise in internet usage is reflected in a general upward trend in online sales, which represented an average of $6.3 \%$ of total retail sales in 2009, growing to $10.7 \%$ by April 2014 (Figure 2). In 2016, online sales 
amounted to a total value of $f_{133 \mathrm{bn}}$ in the UK, indicating an 'exceptional year' for online trading and 16\% growth on 2015 (IMRG Capgemini, 2017). Trends indicate that as a result of increasing accessibility to the internet and concurrent developments in online shopping methods, internet retailing sales have increased. In fact online sales have become an 'integrated' component of retail sales, with similar quarterly trends to the wider retail market in terms of purchasing peaks and troughs although with a greater upward trend since 2009 (ONS, 2014a).

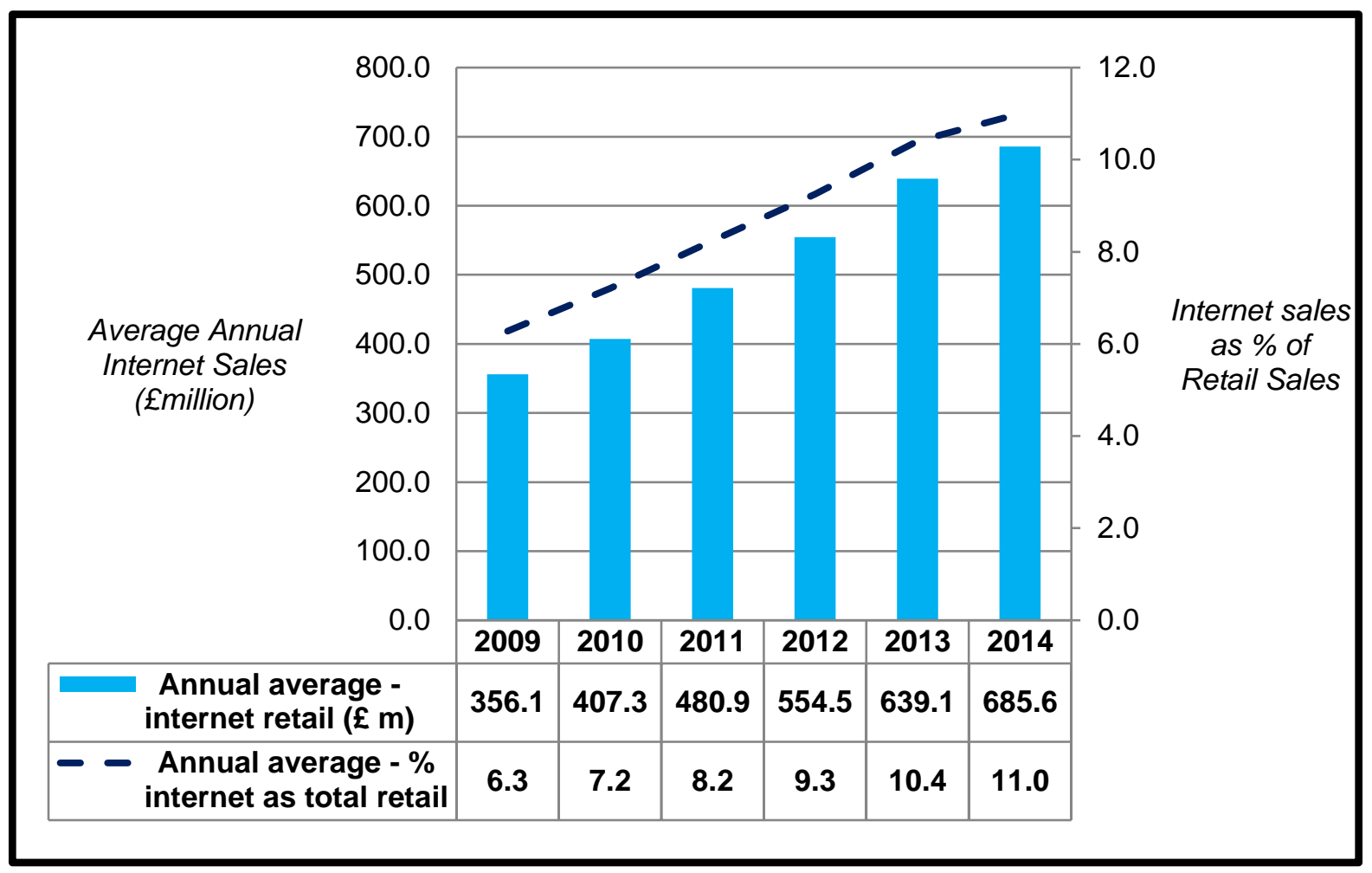

Figure 2: Internet retailing growth 2009-2014

Source: ONS (2014a)

* 2014 figures represent data from January - November2014 only.

However, sectoral retail trends in terms of internet penetration indicate that 'non-store' retailing such as mail order, catalogue and pure-play online retailers has captured the majority of online sales. This sector represents only a very small proportion of retailing overall but constitutes the majority of online per sector sales. For every $f_{1} 1$ spent in the retail sector in April 2014 only 6 pence was spent in non-store retailing (ONS, 2014b). Nevertheless the non-store retailer is where most of the online spending is concentrated, driven by entertainment and pureplay retailers, with $36.4 \%$ of all online retail composed of non-store entertainment sales (Kantar Worldpanel, 2014). 
In terms of the wider retail sector Figure 3 shows that online sales in the grocery sector are a minimal element compared to in-store sales, still below 4\%, albeit on a slight rising trend. This is still an important element of online sales as $42 \%$ of retail spending is spent in food stores. The two sectors where sales have grown most are the textile, clothing and footwear stores (i.e. predominantly fashion retailing) and non-specialised stores (i.e. department stores). The former grew from 7 to $11.7 \%$ in three years, while the latter grew from $6.9-11 \%$ at its peak in quarter four, 2013. Department stores have experienced the largest proportion of year on year growth in online sales, at 30.3\% in 2013 (ONS, 2014b).

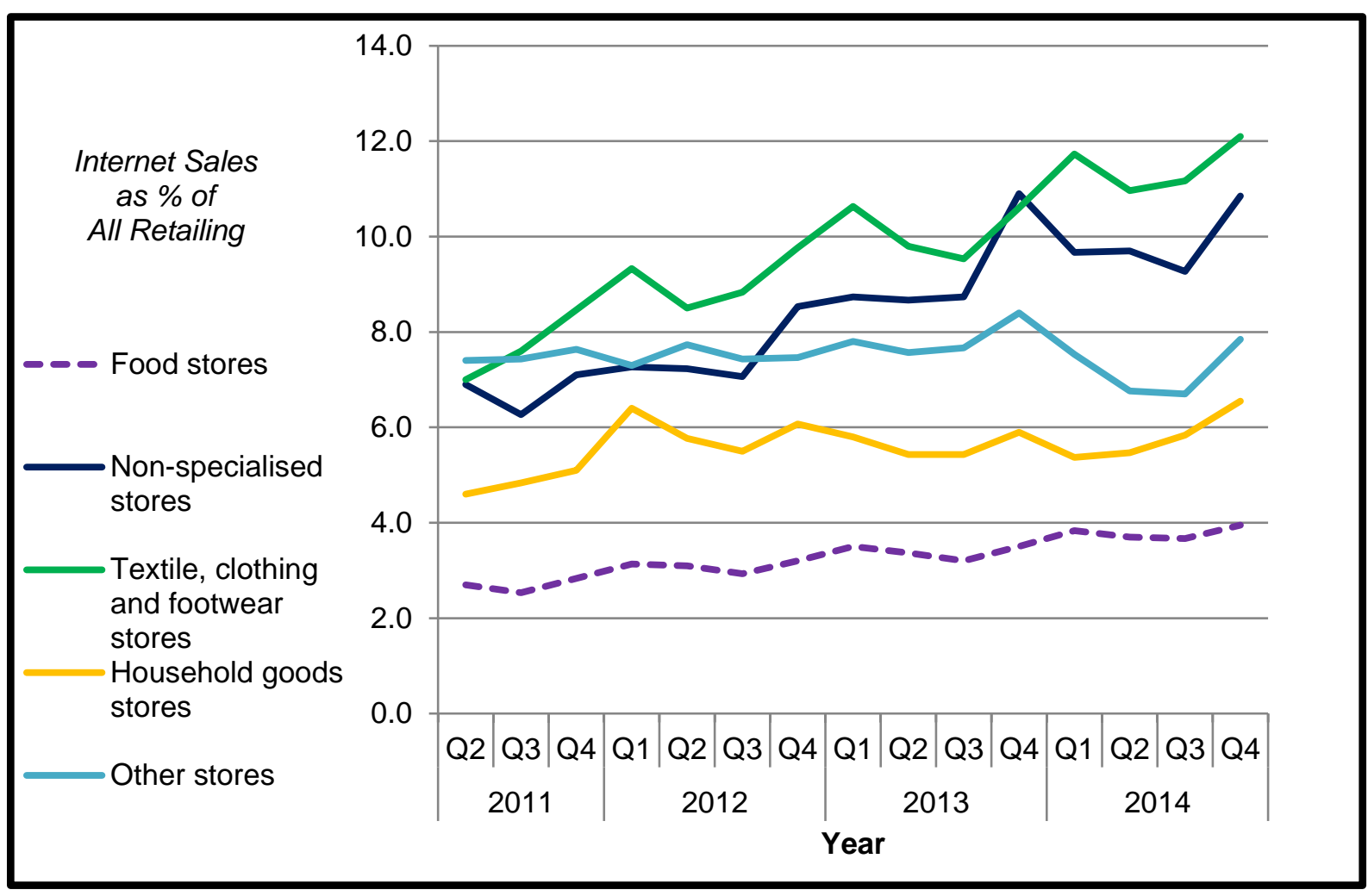

Figure 3 Sectoral online sales as percentage of all retailing (excluding non-store retailing)

Source: ONS (2014a)

The scale of these online trends reveal that they have been gradually increasing in pace with some sectors growing significantly. Financial and travel services have been severely affected with Teale (2013) reporting that between 1998 and 20128000 branches offering financial services and 1250 travel agents closed across the UK. The differential impacts of the diversion or cannibalisation of sales is not simply a question of retail sector but also between types of retailers. Nevertheless CBRE state, 'sales diversion from shops has contributed far less to 
internet sales growth than commonly thought' (Teale, 2013: p2). With 89\% of all sales in 2014 (ONS, 2014a) still occurring in-stores, physical retailers have arguably little to be concerned about thus far, even though the evolution of the online shopping marketplace continues to gather momentum. However, there is a consensus that this is only the beginning of the impact of the internet on shopping centres, and the $11 \%$ of retail transactions not happening in physical stores but online is only set to increase as recent historic trends are predicted to continue.

The implications for individual shopping centres have recently been assessed using the concept of e-resilience by Singleton et al (2016). This cross-sectional study looks not just at the nature of shops in individual centres to create a vulnerability index but also the characteristics of the residents in local catchment areas in terms of their propensity to buy on line. The study has a number of acknowledged data limitations and the statistical model has not been calibrated by reference to actual e-resilience. Nevertheless the results have plausibility with large metropolitan retail centres appearing to be the most resilient together with smaller centres focused on convenience shopping. The most vulnerable centres were found to be 'secondary and medium sized centres' already identified as struggling in the previous section. These results suggest that shopping centre type rather the characteristics of the local population are the key determinant of e-resilience.

\section{The physical retailing response to online sales}

As consumers across all age ranges become increasingly connected to the web online retail is becoming an accepted and normalised way of shopping in various dimensions. Purchasers who buy online can collect in a store and may undertake further purchases. The collection in stores is being improved through internal redesign and the speed of the customer experience (ExperienceLab, 2013). $\mathrm{O}_{2}$ (2014) notes that 85\% of online shoppers in 2013 returned products to stores and $75 \%$ collected items they bought online from a local shop, while stores remain a major source of advice. In this way retailers with a visible and recognisable brand encourage consumer trust and utilise stores to attract online sales.

The growth of 'click and collect' has stimulated an expansion of networks of collection points not just in terms of the number of stores that offer the service but other localities, such as lockers in train and petrol stations and post offices. In June 2014, Doddle was launched in Network Rail stations across the UK. This service provides the first 'fully dedicated, staffed, 
online shopping collection and returns service' (Network Rail, 2014). Across the UK, there are now 81 dedicated Doddle stores, where goods purchased online can be collected (Doddle, 2017). Today, shoppers can purchase certain goods from a particular store without any direct interaction with the physical store itself, and conveniently pick up the goods where it suits them. In this respect, by creating a 'middle man' for distribution, some smaller retailers may benefit as this provides another medium for distributing goods via click and collect, which isn't contingent on visiting their store specifically.

It can mean that a retailer with a strong brand and an online presence can reduce their physical store network. Jessops, a camera retailer, is such an example: as part of major restructuring it promoted online sales and reduced its stores from 187 in 2013 to 51 in 2016 (BBC, 2013; Jessops, 2016). Some of these stores are located within supermarkets. In fact there is an apparent industry consensus that online sales will lead to a substantial decline in retail space, only the scale of the predictions vary (eg Deloitte, 2013; Hammerson, 2013).

Click and deliver is the primary mode of online sales of groceries by supermarkets using their extensive retail network as bases. There have been recent developments in space utilisation by grocery retailers regarding click and deliver. Large supermarket chains, Tesco, Asda and Waitrose, have all opened 'dark supermarkets', which cater exclusively for the online shopper. As with any other grocery order, the shopping list is picked from the shop floor and delivered to the consumer. The exception here is that these supermarkets are not accessible to the public, increasing the efficiency of collection and distribution for the supermarket, whilst resulting in less human traffic in publicly accessible stores (Wood, 2012). The latest innovation is that an online order can be delivered to an alternative location, where it can then be collected. Asda introduced online grocery services at six London tube stations in November 2013, allowing orders taken before noon to be picked up from the station car park after 4pm (Odell and Pickford, 2013). So far these online initiatives have had virtually no impact on real estate occupation and locations of supermarkets.

There are less sophisticated internet strategies available to small retailers. Weltevreden et al. (2005) classify such strategies as information provision that can range from a billboard approach that simply makes potential customers aware of a retailer through to a catalogue, and may include directions to the (nearest) store. Additional services encompass enhancing their relationship with customers including online ordering but without online sales. These strategies 
allow retailers to potentially expand their sales beyond their natural catchment area. However, traditional high street retailers are likely to find that customers are still deterred by the car parking issues discussed earlier, if they need to collect items purchased online. Use of the internet may only expand sales very successfully for specialist retailers such as antique and second hand book sellers where customers are prepared to travel long distances in search of specialist items (Whewell, and Souitaris, 2001).

The role of size is an important issue. The internet allows new retailers arguably lower set up and running costs than opening a shop, but without a recognisable brand/presence to support sales. However, in general small businesses have been slow to take up the opportunities offered by the internet (Wagner et al, 2003). Sole high street retailers can operate click and deliver that may expand local catchment areas but the impact is likely to be modest and will simply displace demand, and such opportunities are probably limited to specialist shops. It may also simply replace phone and deliver too. And as noted earlier click and collect is constrained by accessibility issues. The scope for smaller to medium sized and new retailers to exploit multichannel online sales has so far been limited, implying few if any ramifications for neighbourhood and suburban shopping centres. . The emergence of independent service providers offering collection point networks could logically stimulate retail opportunities for small firms and bolster small scale retail sales. Smaller retail units on suburban high streets and centres may also prove attractive to internet retailers who wish to have presence and visibility in a locality at a cost effective scale.

Overall large multiples selling comparison/fashion goods appear to be in the best position to succeed in this evolving 'click and collect'/ 'click and deliver' market place, supported by brand recognition, an existing network of shops and access to the necessary investment capital for the heavy development costs. Part of this investment is in adapting the physical retail space, for example by transforming shops to act as 'showrooms' enabling consumers to examine products before buying online (Thompson, 2012). In addition it is argued that retailers can enhance the purchasing experience, turning shopping into an 'event' and entertainment (Dennis et al, 2002), creating a 'destination store mind set' (Katros, 2000, p.76). This argument can be set in the wider shopping centre context where their attractiveness is based on their appeal to the 'leisure-tourist-shopper' rather than just the functional/utilitarian shopper (Howard, 2007). 
Given these perspectives it is not surprising that 'click and collect' services have been predominantly used for fashion retailing, with $46.5 \%$ of users purchasing clothing or footwear (Turner, 2013). The review above suggests that it is the large multiple retailers with a strong fashion component that are the primary retailers adapting to online sales by changing their real estate portfolios and hence driving any changes to the retail hierarchy. The remainder of the paper therefore focuses on the strategies of fashion and department chain store retailers.

\section{Analysis of the strategies of fashion and department chain stores}

The research focuses on three market leading retailers to omni-channel online shopping: Next, John Lewis and Debenhams. Next is the largest 'high street' fashion chain in the UK and seen as a ubiquitous presence in prime locations of city/town shopping centres throughout the country. The latter two have the largest department store networks in the UK that act as the bedrock of city and out of town shopping centres. Although these retailers do not offer entirely comparable goods, they were chosen as recognisable and leading retailers with embedded and continually evolving internet strategies. Each of these physical retailers has embraced the internet, and multi-channel shopping is now central to their corporate retail strategy (Jones and Livingstone, 2015a). The analysis is partly based on three semi-structured interviewees (one for each retailer), with two property directors and one property acquisitions manager were carried out at each retailer headquarters in London. The interview process was guided by overarching themes for discussion in order to address the research's objectives. Three themes were broadly addressed in the interviews notably: the specific response of the retailer to online retailing and its impact so far; how internet strategies have become embedded into corporate strategy and decision making; and the impact on physical real estate assets. In addition shifts in retailer locations and possible effects on the hierarchy are considered by reference to the changing network of Next stores using CoStar data.

This analysis identified the current locations of Next stores across the UK, derived from their website, combined with historic information on leasing transactions from the CoStar database, thus offering insight into how the retailer's locational strategies have evolved since 1987. The CoStar database has a wide remit offering market information on a subscription basis. It provides intelligence on all commercial properties in the UK covering a wide range of sectors such as offices, industrial, retail, land, mixed-use and hospitality. The CoStar database gives access to what can be described as the UK most comprehensive record of commercial real estate 
market activities compiled and independently verified by the largest property research team (CoStar Review, 2013). CoStar's proprietary data is sourced directly from property agents, investors and other relevant stakeholders.

\section{Locations of Next stores}

As of February 2016, Next had 512 stores across the UK, including in town locations $(38.3 \%)$, out of town locations $(61.1 \%)$ and airports (0.6\%) (see Table 1). Its out of town offering is dominated by retail parks, and its in town offering by centres, rather than high streets. Of these stores, $88.9 \%$ can be classified as multi-channel retailers, with $4.5 \%$ clearance stores and $6.6 \%$ exclusively home stores, with no clothing on sale. It is arguably no longer a predominantly a 'high street' retailer.

Table 1: Percentage of Next Stores by Shopping Centre Type in 2016

\begin{tabular}{|l|c|c|}
\hline & Number of Stores & \% Stores \\
\hline Airport & 3 & 0.6 \\
\hline High Street & 61 & 11.9 \\
\hline In town centre & 135 & 26.4 \\
\hline Out of town centre & 30 & 5.9 \\
\hline Retail park & 283 & 55.3 \\
\hline Total & $\mathbf{5 1 2}$ & $\mathbf{1 0 0}$ \\
\hline
\end{tabular}

Source: Next website store locator, http://wmw.next.co.uk/stores/

The CoStar data provided historic transactions/lease data on 172 stores, representing $34 \%$ of the current overall store portfolio, from 1987 - 2015, a time series of 28 years. The openings of the 146 new stores since 1987 are not concentrated in any particular area, but are geographically dispersed throughout every part of the UK. From 1987 - 2002, of the 26 stores where Next took tenancies, the trend for opening new stores was still dominated by in town openings, with 15\% opened in high street locations and 54\% in town shopping centres. At this time, only a small number of openings were out of town centres ( $8 \%$ ) and in retail parks $(23 \%)$. Since 2003 however, the of the 146 new stores opening, the trend is very different - with only 45 new stores opening in in-town shopping centres (28) and the high street (17). The majority of new stores opening are in retail parks, which represent $67 \%$ of new leases since 2003. 
The trend is clear: Next is acquiring and increasing its amount of space out of town, and the evidence indicates that in some instances an opening in a retail park is associated with a closure in a nearby town centre. Its latest unified format stores combining male and female fashion, home furnishings and a coffee shop are suited to, if not designed for, the flexibility of large units in retail parks.

\section{Responses, Strategies \& the Impact of Online Retail on Real Estate}

The interviews with the three major retailers reveal that the growth in online shopping is becoming a key consideration in their real estate decision making. The adjustments to accommodate online sales are progressive and implicit rather than revolutionary within their retail strategies, when it comes to considering physical store portfolios. Responding to the internet influence is seen as important for a retailer's market position, encompassing brand image and competitiveness. The analysis below focuses on the real estate element in these strategies.

Debenhams suggested that the opening of new stores was very much dependent on whether the offering was the 'right store, [in the] right market'. The retailer still has a long list of requirements for locations that it is not yet present in, and although its property portfolio is expanding, due to restrictive longer lease terms it has approximately one million square feet of redundant, excess space. Today, size formats and requirements are analysed on the back of what is happening online... shopping habits are changing'. New retail spaces being considered by Debenhams today are around '30-40\% smaller than space we would have taken $30-40$ years ago'. Debenhams is opening smaller boutique type stores, primarily but not exclusively in out of town locations and retail parks. They noted that opening a new store as a 'showcase', saw online penetration in that locality increase by $30 \%$, indicating that online and physical retailing have a symbiotic relationship for the retailer. When considering a new location, Debenhams will assess online penetration in the area, the location in relation to local retailing and whether the location can meet their property specific requirements.

Next also adopt a similar bottom up, location-by-location, 'right store, right market' approach to their new requirements, similar to that discussed by Debenhams, and will consider in town locations if they sit attractively within their strategy. However as a predominantly leasehold business, with a weighted average unexpired lease term of only 6 years across their whole portfolio, they are much more focussed on having the flexibility associated with shorter 
leases and are consistent when considering new leases in their strategy: 'we are very rigorous, we ain't going to sign up for 25 years, 10 is the norm, in an exceptional location we'll sign up to 15, but that's it.' Such fluidity in their approach as an occupier reinforces the CoStar trend analysis of flexible expansion in recent years into retail parks and out of town centres, and this presence is seen to be 'vital' to their online success, in terms of being accessible to consumers. John Lewis, which remains 65$70 \%$ freehold /long leasehold, is also looking to expand their current portfolio of 46 stores and expect that the 'estate will be 50-55, by 2020, we might get to 60'. The varied ways in which the retailers hold properties in their portfolio, combined with their retail strategies is a key influence in how they integrate and deliver online retailing.

The expansion of 'click and collect' is seen as a central strategy for these major UK brands, taking advantage of their networks and rather than contracting the number of physical stores they are expanding, and now providing dedicated collection areas for click and collect customers. However, even though John Lewis operates less in out of town locations, they have seen a marked increase in the take up of click and collect, which is growing 'exponentially, accounting for $50 \%$ of our online sales'. Nevertheless certain types of goods are more appropriate for click and collect and contingent on particular locations; 'you wouldn't visit John Lewis on Oxford Street to pick up a freezer, for example'.

The impact of the online shopping phenomenon clearly plays an important role in the strategy of each of the three retailers interviewed, but it is one which requires significant capital expenditure to continually develop, with Debenhams noting that they currently 'see our online growth increasing year on year, it is significant each year and that is reflective of the amount of investment we are putting into it.' From the perspective of leading retailers, their size means they are in a position to invest substantial capital into ensuring they are at the vanguard of the online offering. In line with the literature assessed, smaller stores may be less able to take the risk of investing capital into online offerings which may not prove successful. Smaller retailers are viewed as having a different target market as well as 'smaller budgets...property porffolios and economies of scale...I don't think they can compete to the same extent that we [as a leading retailer] can'. John Lewis also reflected on the 'immaturity' of the online market, as it has a very different cost model to physical retailing, due to fixed costs, therefore its evolving impact is currently more uncertain with increasing risk for smaller retailers with constrained capital. 
The physical retail experience is also of considerable importance to the retailers, with Debenhams emphasising the way shopping has become more spectacular, and the importance surrounding the customer journey, coming into the store, having a theatre like experience, in a nice clean retail environment, having the right product and just creating the right environment for the customers, making it accessible and convenient as well.' John Lewis highlights the importance of strong customer service in a competitive retailing environment, where 'the customer is really king...there is a real challenge around competitiveness, as customers have price comparison at their fingertips, they are constantly looking for a deal...it is the product of the internet ultimately, compounded by the recession'. Retailing is now much more complicated than it was a decade ago, and stores need to differentiate themselves from the competition. John Lewis discusses the ideal as a 'really strong online and a strong store, the store will be all about experience and outstanding service... The one thing online can't replicate is human interaction and that will sustain the shops going forward and keep the experience dynamic for the customer as well.'

The accounting relationship between (click and collect) online and store sales represents a challenge. Debenhams take the 'wired' approach as discussed by Worzala et al (2002), with sales 'attributed to each store, rather than a separate budget, so the online sales helps the overall performance of the store.' However, Next take a different approach, with four separate streams in operation within their business model, with the directory (which includes both catalogue and online), distinctly separate from the stores, the younger fashion brand Lipsy, and Next Sourcing, a subsidiary. The reason for this is to allow Next to assess stores on their own merit, as 'online can flatter the store performance and you might never get a true picture of the store'. Another reason for not adopting this 'wired' approach is because it could be challenging to link specific online sales definitively to one store - a customer may purchase from one store, buy online, then return both items to an entirely different store - so as 'tracking data is always is a challenge, unpicking information is very difficult'.

The overarching message emerging from the interviews is that online retailing complements the in-store experience and enhances profitability overall for these retailers. Online sales are expected to continue growing and are 'much more cost effective than selling goods from stores'. The adoptions of internet shopping platforms, offering an efficient and attractive multi-channel retail experience are central elements within the real estate strategies of the three retailers. Retailers are conscious of, and respond to, possible cannibalisation effects from online to physical stores, however the halo effect, where online sales actually reinforces sales in-stores, was discussed as a positive and significant knock-on effect from online shopping by all interviewees. The 
interaction between online and physical stores means that opening a new store stimulates local online sales, but it is also difficult to ascertain how successful the online offerings, such as click and collect are proving to be for retailers. Unlike the expectations of falling aggregate retail space noted above, Debenhams, Next and John Lewis all continue to extend their store networks, with Debenhams and Next predominantly (but not exclusively) favouring out of town locations. These leading retailers are unlikely to be atypical, and so click and collect has reinforced the populating of retail parks with fashion retailers and contributes to the restructuring of these types of shopping centres away from bulky goods

\section{Conclusions}

There is little doubt that online shopping has been highly influential on retailing over the last ten years but substantive changes in the urban retail hierarchy precede this phenomenon. The proportion of online sales at $11 \%$ in the UK probably underestimates the magnitude of its effect because it has occurred at a time of falling real incomes and consumer spending and it has been focused in particular sectors. Online retailing has become an inherent and central element within major retailers' businesses and therefore real estate strategies, with considerations such as online marketplace penetration and possible 'cannibalisation' coming to the fore in decision making.

Nevertheless internet retailing is only a contributing factor to changes in the retailing hierarchy and shopping centres. British high streets have always been subject to change not least in the mix of shops, particularly with the long term decline of specialist grocery shops and the rise of the supermarket. With the advent of the car the shopping hierarchy has been diffused, with greater decentralisation in the form of out of town shopping centres and retail parks. Larger sub-regional shopping centres curiously have also benefitted at the expense of small towns, while suburban centres have also been in decline.

These changes have meant that the term 'high street' has become ambiguous but is often used liberally as reference to any traditional shopping centre and if used specifically, normally to small town retail centres. The confusion is reinforced by the fact that Next, the largest 'high street' UK fashion retailer now has more shops in retail parks than in town/city centres. This fact is symbolic of the changes that have occurred to the retail hierarchy. It is doubly symbolic because the acceleration of Next's move out of town has coincided with it embracing an omni- 
channel approach to retailing. Online retailing has tended to reinforce decentralisation trends within urban areas.

'Click and collect' stresses convenience and is symbiotic with the out of town retail trend, with outlets offering convenient collection locations. Retail parks/warehouses that began life as predominantly bulky goods stores could have potentially suffered a fatal blow by the internet. Online retailers offering 'click and deliver' combined with easy price comparison was arguably more attractive for standard electrical goods that formerly needed to be collected by car from a retail warehouse. But even before the growth of internet sales major fashion brand retailers were expanding in to these locations giving retail parks a new role. This trend has now been consolidated and enhanced by 'click and collect' and 'showrooming'.

Meanwhile city centres have been partially successful because their size operates as a magnet for shoppers, but also because they are attractive to leisure shoppers looking for a 'day out' experience. This will be augmented by multi-channel retailers seeking to use their stores as destinations to showroom their goods. Department shops that had been in long term decline have benefitted from having an established brand and their range of goods on offer on-line in one place, the financial resources to promote click and collect, and are experiencing a revival. Our findings indicate that the position of major retailers in city centres is bring consolidated and enhanced by online retail, through both the click and collect services and the 'halo' effect experienced.

Small towns already recognised as regressing are unlikely to benefit from online retailing, partly because of the car parking limitations they suffer from, which could make collection challenging. Retail parks are better placed and have larger units for major retailers. In addition while large retailers have embraced online retail sales strategies the internet at least so far offers very few opportunities for existing small (suburban) high street retailers, where the benefit of implementing an online retail strategy may be outweighed by the risks and costs associated with setting up and operating such a system. Any positive impact of online sales is bypassing suburban centres and small towns already in decline, and so are not a salvation and a way forward for these retailers. The relative plight of these high streets has been worsened by the internet due to the contraction of the networks of certain personal services providers, such as banks and travel agents, with consequences for local footfall. 
These conclusions remain to a degree tentative, even speculative as the online revolution is still in its infancy. At present retailer size is a crucial determinant for entry to the on line market but this could change with the expansion of independent collection point networks. It is possible that there will be a retrenchment in space occupied by well-known brands in the large established retail centres across the UK but this will be balanced by new space taken up in out of town locations. It seems unlikely that the internet will lead to a point in the near future where there is predominantly an 'online high street' where we buy our goods via our computers. Instead elements at least of the high street are moving online. Retailers will in the main opt for a physical presence, where shopping is an experience, with the opportunity to browse in-store, and use of the 'high street online' if desired. In terms of shopping centres the overall impact on the urban retail hierarchy is likely to be a continuation of differential changes already in tow. 


\section{References}

Barlow, A.K.J., N.Q. Siddiqui, and M. Mannion. 2004. "Developments in information and communication technologies for retail marketing channels", International Journal of Retail and Distribution Management, 32 (3): 157 - 163.

BBC. 2013 "Jessops camera stores to close with loss of 1,370 jobs". BBC, 11th January. http://www.bbc.co.uk/news/business-20992125 (accessed March, 2014)

Burt, S., and L. Sparks. 2003. "E-commerce and the retail process: a review", Journal of Retailing and Consumer Services, 10 (5): 275-286.

CBRE. 2014a. UK Retail Warehouse Parks in the Pipeline: Market View, London: CBRE.

CBRE. 2014b. UK Shopping Centres in the Pipeline: Market View, London: CBRE.

Centre for Retail Research. 2013. Retail in 2018 - Shop numbers, Online and the High Street, University of Nottingham. http://www.retailresearch.org/retail2018.php [accessed March 2014].

Chaffey, D., F. Ellis-Chadwick, R. Mayer, and K. Johnston. 2009. Internet Marketing: Strategy, Implementation and Practice. Fourth edition, Harlow: FT Prentice Hall.

Charlesworth, A. 2009. Internet Marketing: A Practical Approach. Oxford: Butterworth-Heinemann, Elsevier.

Competition Commission. 2008. The Supply of Groceries in the UK Market Investigation: Final Report, London: Competition Commission.

Cope, N. 1996. Retail in the Digital Age, London: Bowerdean.

CoStar 2013. Investment Review, www.propex.co.uk/investment/pdfs/2013 investment bulletin public.pdf. [accessed March 2014].

Crosby N., C. Hughes, C. Lizieri and M. Oughton. 2005. Message from the Oracle: The land use impact of a major in-town shopping centre on local retailing, Journal of Property Research, 22 (2-3): 245-265.

Cushman and Wakefield. 2013. Global Perspective on Retail: Online Shopping, London: Cushman and Wakefield.

Deloitte. 2013.. The Store of the Futute: The New Role of a Store in a Multi-Channel Enviornment. http://www.deloitte.com/assets/Dcom-

Germany/Local\%20Assets/Images/06 CBuT/2013/CB R store of the future 2013.pdf [accessed March 2014].

Digital High Street Advisory Board 2015. Digital High Street 2020.

$<$ http:/thegreatbritishhighstreet.co.uk/digital-high-street-report-2020> [accessed January 2017].

Doddle 2017. https://www.doddle.com/locations [accessed January 2017]. 
Doddy, A. F. and W. R.. Davidson. 1967. "Next revolution in retailing", Harvard Business School, 45 (May-June): 4-16.

Doherty, N.F. and F. Ellis-Chadwick. 2010. "Internet retailing: the past, the present and the future", International Journal of Retail and Distribution Management, 38 (11/12): 943 - 965.

Doherty, N.F. and L. McAuley. 2002. "Towards the formulation of a comprehensive framework for the evaluation of investments in sell-side e-commerce", Evaluation and Program Planning, 25 (2): 159-165.

Dolega, L., M. Pavlis and A. Singleton. 2016. "Estimating attractiveness, hierarchy and catchment area extents for a national set of retail centre agglomerations", Journal of Retailing and Consumer Services, 28 (1):78-90.

Durand, C. and N. Wrigley. 2009. "Institutional and economic determinants of transnational retailer expansion and performance: a comparative analysis of Wal-Mart and Carrefour", Environment and Planning A, 41 (7): 1534-1555.

Ellis-Chadwick, F., N. Doherty and C. Hart. 2002. "Signs of change? A longitudinal study of Internet adoption in the UK retail sector". Journal of Retailing and Consumer Services, 9 (1): 71-80.

Ellis-Chadwick, F., N.F. Doherty and L. Anastasakis. 2007. "E-strategy in the UK retail grocery sector: a resource-based analysis", Managing Service Quality: An International Journal, 17 (6): 702 727.

Fillis, I., U. Johannson and B. Wagner. 2004. "Factors impacting on e-business adoption and development in the smaller firm”, International Journal of Entrepreneurial Behaviour \& Research, 10 (3): 178-191.

Genecon. 2011. Understanding High Street Performance, London: Department of Business Innovation and Skills.

Guy, C. 2000. "From crinkly sheds to fashion parks: the role of financial investment in the transformation of retail parks", International Review of Retail, Distribution and Consumer Research, 10 (4): 389-400.

Hammerson. 2013. The Reshaping of Retail, London: Hammerson plc.

Howard, E. 2007. "New shopping centres: Is leisure the answer?", International Journal of Retail and Distribution Management, 35 (8): 661 - 672.

IMRG Capgemini, 2017. IMRG Capgemini Retail Sales Index: UK online sales exceed £130 billion in 2016, fuelled by sales from smartphones. https://www.uk.capgemini.com/news/uk-news/imrg-capgemini-e-retail-sales-index-uk-onlinesales-exceed-ps130-billion-in-2016 [accessed January 2017]

Jessops (2016) Storefinder, http://www.jessops.com/storefinder. 
Jones, C. 2014. "Land use planning policies and market forces: Utopian aspirations thwarted?", Land Use Policy, 38 (5):.573-579.

Jones, C. 2016. Spatial economy and the geography of functional economic areas, Environment and Planning B, http://journals.sagepub.com/doi/abs/10.1177/0265813516642226 [accessed January 2017]

Jones, C. and N. Livingstone. 2015a. "Emerging implications of online retailing for real estate: Twenty-first century clicks and bricks", Journal of Corporate Real Estate, 17(3), pp.226-239.

Jones, C. and N. Livingstone. 2015b. "The Restructuring of the UK Urban Retail Hierarchy and the Consequences for Real Estate Investment", Paper presented to the annual conference of the European Real Estate Society, Istanbul, June, 2015.

Jones, C. and A. Orr. 1999. "Local commercial and industrial rental trends and property market constraints”, Urban Studies, 36 (2): 215-229.

Kantar Worldpanel. 2014. Online on track? The world of online retail. An insight report, Kantar Worldpanel.

http://www.kantarworldpanel.com/global/News/Online-on-track-The-world-of-online-retail [accessed July 2015]

Katros, V. 2000 "A note on internet technologies and retail industry trends", Technology in Society, $22(1): 75-81$.

Laudon, K. and C. Traver. 2012. E-Commerce 2012, Business, Technology, Society. Tength edition, Boston: Pearson,.

Local Data Company. 2011. Shop vacancy rates stabilise in 2011 but the gap between the best and worst performing towns widens and over $14 \%$ of shops still remain vacant, Press Release, Local Data Company, $8^{\text {th }}$ September.

Mitchell, P. 2014 The Size and Structure of the UK Property Market 2013: A Decade of Change, London: Investment Property Forum.

Network Rail. 2014. "Doddle joint venture rolls out across UK", $18^{\text {th }}$ June . Available at: http://www.networkrail.co.uk/news/2014/jun/Doddle-joint-venture-rolls-out-across-UK/

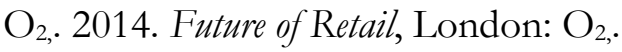

Odell, M. and J. Pickford. 2013. “Amazon eye's gap as Tube's 24 hour move signals the end for ticket offices", Financial Times, $21^{\text {st }}$ November.: http://www.ft.com/cms/s/0/bc5024ce-528c11e3-8586-00144feabdc0.html\#axzz3Hegh0JjG accessed March 2014].

ONS. 2014a. "Retail Sales: November 2014”, ONS Statistical Bulletin, November 2014.

ONS. 2014b. "Internet Access - Households and Individuals, August 2014", ONS Statistical Bulletin, August 2014.

ONS. 2016a. "Retail Sales in Great Britain: Nov 2016", ONS Statistical Bulletin, November 2016. 
ONS. 2016b. "Internet Access - Households and Individuals: 2016", ONS Statistical Bulletin, August 2016.

Portas, M. 2011. The Portas Review An independent review into the future of our high streets, London: Department for Communities and Local Government

Reynolds. J. and R. Schiller. 1992. A new classification of shopping centres in Great Britain using multiple branch numbers, Journal of Property Research, 9 (2): 122-160.

Rohm, A. J. and V. Swaminathan. 2004. "A typology of online shoppers based on shopping motivations". Journal of Business Research, 57 ( 7): 748-757.

Rowley, J. 2009. "Online branding strategies of leading UK fashion retailers", Internet Research, 19 (3): 348-369.

Rubin, M. 2013. Online shopping to bit £,50bn by 2018. http://www.verdictretail.com/onlineshopping-to-hit-50bn-by-2018/ [accessed March 2014].

Schiller, R. 1986. "Retail decentralisation: The coming of the third wave", The Planner, July:13-15.

Singleton, A.D., L. Dolega, D. Riddlesden and P.A. Longley.2016. "Measuring the spatial vulnerability of retail centres to online consumption through a framework of e-resilience", Geoforum, 69 (1): 5-18.

Teale, M. 2013. The internet leviathan slows, London: CBRE.

Thomas, C., R. Bromley and A. Tallon. 2006. "New 'high streets' in the suburbs? the growing competitive impact of evolving retail parks", International Review of Retail, Distribution and Consumer Research, 16 (1): 43-68.

Thompson, C. 2012. "Shops will be "little more than showrooms". Financial Times, 28 October http://www.ft.com/cms/s/0/e6ef4454-2122-11e2-babb-00144feabdc0.html

Turner, L. 2013. "Click and Collect... set to be worth f4bn in the UK by 2018", http://www.mwb-online.co.uk/Articles/Click-Collect-to-be-worth-\%C2\%A34bn-in-2018.aspx [accessed March 2014].

Wagner, B.A., I. Fillis and U.Johansson. 2003. "E-business and e-supply strategy in small and medium sized businesses (SMEs)", Supply Chain Management: An International Journal, 8 (4): 343 354.

Weltevreden, J. 2007. "Substitution or complementarity? How the Internet changes city centre shopping", Journal of Retailing and Consumer Services, 14 (3), 192-207.

Weltevreden, J.W.J., O.A.L.C. Atzema and R.A. Boschma. 2005. "The adoption of the internet by retailers: a new typology of strategies", Journal of Urban Technology, 12 (3):.59-87. 
Whewell, J.A. and V. Souitaris. 2001. "The impact of internet trading on the UK antiquarian and second-hand bookselling industry", Internet Research: Electronic Networking Applications and Policy, 11 (4): 296-309.

Wood, Z. 2012. "Rise of the dark store feeds the online shoppers", Guardian, 30 November. http://www.guardian.co.uk/business/2012/nov/30/dark-stores-feed-dotcomshoppers?INTCMP $=$ SRCH [accessed March 2014].

Worzala, E. M., A.M. McCarthy, T. Dixon and A. Marston. 2002. "E-Commerce and retail property in the UK and USA", Journal of Property Investment and Finance, 20 (2):142-158.

Wrigley, N. and Lambiri, D. 2014. High Street Performance and Evolution: A Brief Guide to the Evidence. University of Southampton, Southampton,

$<$ http://thegreatbritishhighstreet.co.uk/pdf/GBHS-HighStreetReport.pdf > (accessed July 2015).

Wrigley, N. and Dolega, L. 2011. "Resilience, fragility and adaptation: new evidence on the performance of UK high streets during global economic crisis and its policy implications", Environment and Planning A, 43 (10):, 2337-2363. 